УДК 551.21:552.11

ПОЗДНЕТРИАСОВЫЕ ВУЛКАНИТЫ ТАЛЬМИНСКОГО КОМПЛЕКСА (ЮГО-ЗАПАДНОЕ ПРИМОРЬЕ): МИНЕРАЛОГИЯ, ГЕОХИМИЯ И ГЕНЕЗИС

\author{
Чащин А.А., Чащин С.А., Касаткин С.А., Голозубов В.В. \\ ФГБУН «Дальневосточный геологический институт» Дальневосточного отделения \\ Российской академии наук, Владивосток, е-таil: achashchin@mail.ru
}

Впервые представлены детальные петрографические, минералогические, геохимические (петрогенные оксиды, редкие и редкоземельные элементы) данные, а также оценки Р-Т параметров кристаллизации вулканических пород позднетриасового тальминского комплекса северной части Лаоелин-Гродековского террейна (Юго-Западное Приморье) в бассейне реки Молоканка. Стратифицированные образования комплекса представлены здесь главным образом андезитами и дацитами, а также их кластолавами. Показано, что умеренно кислые вулканиты тальминского комплекса характеризуются повышенными концентрациями $\mathrm{Sr}, \mathrm{Rb}$, Ва и низкими - Nb, Та и Ti, что считается типоморфным признаком эффузивных пород надсубдукционного происхождения. Это подтверждается также расположением точек составов проанализированных образцов на ряде дискриминантных диаграмм, используемых для реконструкции геодинамических обстановок формирования базальтов и андезитов. Однако данному предположению противоречат геологические сведения по строению Лаоелин-Гродековского террейна - отсутствие фрагментов аккреционного клина и пород океанической коры триасового возраста. Предполагается, что источником первичных магм для позднетриасовых вулканитов тальминского комплекса являлось мантийное вещество, метасоматически переработанное в ходе предшествующей позднепермской субдукции. Основываясь на составах клино- и ортопироксенов, а также химизме валовых составов пород, определили РТ-условия формирования андезибазальтов, андезитов и дацитов тальминского комплекса. Показано, что кристаллизация высокоглиноземистых андезибазальтов и умеренномагнезиальных андезитов комплекса происходила в диапазоне температур $1076-1061^{\circ} \mathrm{C}$ и соответственно $1099-1076^{\circ} \mathrm{C}$. Для низкомагнезиальных андезитов и дацитов присущи более низкие по сравнению с умеренномагнезиальными андезитами температуры кристаллизации расплава: $1014-996^{\circ} \mathrm{C}$ и соответственно $993-983^{\circ} \mathrm{C}$.

Ключевые слова: Лаоелин-Гродековский террейн, триасовый вулканизм, Юго-Западное Приморье, геодинамические обстановки

\title{
LATE TRIASSIC VOLCANIC ROCKS OF TALMINSKY COMPLEX (SOUTHWESTERN PRIMORYE): MINERALOGY, GEOCHEMISTRY AND GENESIS
}

\author{
Chashchin A.A., Chashchin S.A., Kasatkin S.A., Golozubov V.V. \\ Far East Geological Institute of Far Eastern Branch of the Russian Academy of Sciences, \\ Vladivostok,e-mail: achashchin@mail.ru
}

\begin{abstract}
The results of mineralogical, geochemical, petrographic and other petrologic studies as well as assessment of PT parameters of crystallization of volcanic rocks of Late Triassic Talminsky complex are presented for the first time. The complex is mapped in the northern part of the Laoelin-Grodekovo terrane, within the Molokanka River basin, in the southwestern Primorye. Bedded deposits of the complex mainly consists of andesitic and dacitic rocks and their clastic lavas. Geochemical analyses of the moderately silicic volcanic have shown high concentrations of $\mathrm{Sr}, \mathrm{Rb}$, and $\mathrm{Ba}$ and low concentrations of $\mathrm{Nb}, \mathrm{Ta}$, and $\mathrm{Ti}$ which are characteristic features of suprasubduction rocks. This is also indicated by compositions of these rocks plotted on discrimination diagrams used for reconstruction of geodynamic settings of formation of basalts and andesites. However, geologic data available on the LaoelinGrodekovo terrane structure, namely the absence of fragments of accretionary wedge as well as rocks of the Triassic oceanic crust, contradict the above assumption. The source of primary magmas for the Late Triassic volcanics of the complex was probably mantle substance that underwent metasomatic alteration during the Late Permian subduction. The PT conditions of formation of the Talminsky complex andesibasalts, andesites and dacites were determined based on chemical compositions of bulk rock and their clino- and orthopyroxenes. The studied high-alumina andesibasalts and moderately magnesium andesites crystallized at temperature $1076-1061^{\circ} \mathrm{C}$ and $1099-1076^{\circ} \mathrm{C}$, respectively, whereas low-magnesium andesites and dacites had relatively lower temperature of crystallization: $1014-996^{\circ} \mathrm{C}$ and $993-983^{\circ} \mathrm{C}$.
\end{abstract}

Keywords: Laoelin-Grodekovo terrane, Triassic volcanism, southwestern Primorye, geodynamic setting

Долгое время считалось, что триасовые отложения на юго-западе Приморья представлены исключительно терригенными прибрежно-морскими и континентальными угленосными фациями. В частности, в пределах Лаоелин-Гродековского террейна (фрагмента позднепалеозойской-раннемезозойской активной окраины [1], рис. 1, А) была выделена монгугай- ская угленосная свита с остатками весьма специфичной позднетриасовой флоры [2]. Эта свита перекрывает с угловым несогласием сложнодислоцированные позднепермские терригенные отложения, вулканиты и граниты. Однако исследования последних десятилетий показали наличие в пределах рассматриваемого террейна вулканических образований триасового 
возраста, которые были выделены здесь в тальминский базальт-риолитовый вулканический комплекс, объединяющий одноименную толщу и её субвулканические комагматы [3; 4].

Первоначально этот комплекс был выделен на крайнем юго-западе Приморья в составе Тальминской вулканоструктуры (район оз. Птичье) и в краевой части Тигровой вулканоструктуры (г. Бол. Тигровая), большая часть которой расположена в Китае. Вулканиты, слагающие данный комплекс, были отнесены здесь к позднему триасу на основании сопоставления с датированными флорой аналогичными по составу вулканогенными образованиями в прилегающей к Приморью провинции Цзилинь Китая $[3 ; 4]$. В дальнейшем позднетриасовый возраст вулканитов был обоснован данными радиоизотопного датирования (U-Pb метод) - 232.8-212.4 млн лет [5].

Последующие исследования показали, что наиболее масштабно триасовый вулканизм проявился в северной части Лаоелин-Гродековского террейна, где вулканиты комплекса прослеживаются на расстояние порядка 90 км в юго-западном направлении от горы Филюшин Север до границы с КНР. Следует отметить, что триасовые вулканиты описываемого комплекса имеют продолжение на сопредельной территории Китая в западном и юго-западном направлении, что подтверждается работами зарубежных исследователей [6].

В настоящее время сведения о тальминском комплексе ограничиваются, прежде всего, геологическими и петрохимическими данными, которые кратко изложены в геологических отчетах и объяснительных записках к геологическим картам масштаба 1:200 000 и 1:1 000000 [3; 4]. Минералогическая и геохимическая информация о слагающих породах практически отсутствует. В этой связи многие вопросы петрогенезиса и эволюции магматитов, а также геодинамической обстановки их формирования до сих пор остаются нерешенными.

Цель исследования: установление термодинамических параметров кристаллизации вулканических пород позднетриасового тальминского комплекса, распространенного в северной части Лаоелин-Гродековского террейна, а также реконструкция геодинамических условий их формирования на основе детального минералогического и геохимического изучения преимущественно основных и средних по составу вулканитов данного комплекса.
Краткая геологическая характеристика района исследований

В северной части Лаоелин-Гродековского террейна тальминский комплекс впервые был выделен и описан при проведении геолого-съемочных работ (ГДП-200) в пределах листов L-52-XXX, XXXVI. Излившиеся покровы рассматриваемого комплекса с резким угловым несогласием залегают здесь на образованиях силурийско-пермского структурного этажа Лаоелин-Гродековского террейна и прорываются позднетриасовыми (каменушкинский комплекс) и раннеюрскими (гвоздевский комплекс) гранитоидами.

Согласно существующим представлениям в нижней части разреза тальминского комплекса преобладают покровы андезитов, дацитов и их кластолавы и лишь иногда отмечаются потоки андезибазальтов. В верхней части разреза, как правило, распространены риодациты, риолиты и их кластолавы. Помимо эффузивных образований, в основании разреза описываемого комплекса картируются пачки и линзы конгломератов, гравелитов, песчаников и алевролитов. Суммарная мощность свиты приближенно оценивается в 700 м. Позднетриасовый возраст пород тальминского комплекса здесь определяется на основании многочисленных находок ископаемой флоры в прослоях туфогравелитов, алевролито-песчаников из опорного разреза в окрестностях с. Рубиновка. Следует отметить, что ранее на ГК-200 первого поколения [7] описываемые вулканиты были отнесены к барабашской свите позднепермского возраста.

Нами исследовались выходы вулканогенных образований тальминского комплекса в бассейне р. Молоканка на двух участках: левобережье пади Сахалин около села Рубиновка и на правобережье среднего течения р. Молоканка между селами Жариково и Рубиновка (рис. 1, Б).

На первом участке в ходе геолого-съемочных работ был выделен и описан опорный разрез низов изучаемого комплекса. Основание разреза здесь сложено пачкой зелено-серых мелкозернистых туфопесчаников с линзами туфогравелитов и конгломератов. Мощность пачки составляет 235 м. Выше залегает горизонт конгломератов мощностью 45 м, сложенный хорошо окатанными обломками различной размерности песчаников, алевролитов, туфов среднего и кислого состава, дацитов и гранитов. Этот горизонт перекрыт лавовым потоком 
массивных плагиоклазовых и амфибол-плагиоклазовых андезитов, мощность которого составляет 75 м. Выше по разрезу комплекс состоит из переслаивающихся туфопесчаников и алевролитов, содержащих линзы конгломератов. Завершают разрез плагиоклазовые андезиты, а также редкие маломощные потоки андезибазальтов. Общая мощность разреза составляет здесь 460 м. Породы тальминского комплекса прорваны штоками и дайками риолитового состава, являющимися субвулканическими комагматами описываемых вулканитов.

На этом участке основным предметом наших исследований были андезибазальты и андезиты, поскольку они являются наиболее информативными при решении вопросов, связанных с генезисом магматических расплавов и реконструкцией геодинамических условий их формирования.

На втором участке образцы отбирались из естественных изолированных коренных обнажений и искусственных выработок в правом борту долины р. Молоканка. Стратифицированные образования комплекса представлены здесь главным образом эффузивными разновидностями андезитов и дацитов.

\section{Материалы и методы исследования}

Минералого-геохимическое изучение вулканитов тальминского комплекса было выполнено на основе коллекции образцов и проб, собранных в 2019-2020 гг. на вышеперечисленных участках. Для аналитических исследований отбирались образцы с наименьшими признаками вторичных изменений.

Минеральный состав и структуры вулканических пород исследовались в шлифах с использованием современных поляризационных микроскопов «ЛОМО Полам Л-213М» (Россия), Carl Zeiss Axioplan 2 (Германия) (ДВГИ ДВО РАН). Составы породообразующих и акцессорных минералов определялись в лаборатории рентгеновских методов ДВГИ ДВО РАН на микроанализаторе JEOL JXA-8100. Аналитики - Молчанова Г.Б., Екимова Н.И.

Содержание петрогенных оксидов в породах определяли в лаборатории аналитической химии аналитического центра Дальневосточного геологического института ДВО РАН методом атомно-эмиссионной спектрометрии на спектрометре iCAP 7600 Duo (Thermo Electron Corporation, США). Аналитики - Горбач Г.А., Ткалина Е.А., Хуркало Н.В. Определение содержаний редких и редкоземельных элементов выполнено здесь же методом масс-спектрометрии с индуктивно связанной плазмой на спектрометpe Agilent 7500 (Agilent Techn., США). Аналитики - Остапенко Д.С., Еловский Е.В., Зарубина Н.В.

\section{Петрографо-минералогическая характеристика вулканитов}

Андезибазальты - наименее распространенная группа пород тальминского комплекса. Макроскопически это темносерые, с зеленоватым оттенком породы с массивной текстурой и порфировой структурой. Характерной особенностью изученных андезибазальтов является присутствие в них значительного количества крупных вкрапленников плагиоклаза. По соотношению минералов-вкрапленников среди них выделяются плагиоклаз-двупироксеновая и плагиоклазовая разновидности.

Плагиоклаз во всех разновидностях андезибазальтов является доминирующим минералом-вкрапленником. Он представлен крупными (до 4 мм) и мелкими (до 0.5 мм) шестоватыми кристаллами, соответствующими по составу битовниту (72-86 мол. \% An), реже лабрадору и андезину (67-47 мол. \% An). Довольно часто крупные кристаллы минерала имеют прямую зональность, выраженную в падении анортитового минала от центра (87-73 мол.\% An) к краю (71-51 мол.\% An) зерна. Одновременно в краевых зонах кристалла увеличивается содержание ортоклазового минала (1.30-1.82 мол. \% Or). Иногда в центральных частях крупных кристаллов плагиоклаза можно наблюдать следы коррозии, за счет чего он приобретает ситовидный облик. В пустотах проплавления кристаллизуются новообразованный кислый плагиоклаз (43-38 мол. \% An) и реже рудный минерал.

Клинопироксен образует редкие мелкие кристаллы (до 1.5 мм) удлиненно-таблитчатой формы, отвечающие по составу авгиту $\left(\mathrm{Wo}_{40.17-39.62} \mathrm{En}_{44.86-44.78} \mathrm{Fs}_{\text {14.97-15.6 }}\right)$, реже переходным разностям между авгитом и эндиопсидом ( $\left.\mathrm{Wo}_{42.93-43.38} \mathrm{En}_{47.17-47.55} \mathrm{Fs}_{9.85-9.07}\right)$. Ocoбенностью отдельных кристаллов минерала является наличие в них примеси $\mathrm{Cr}_{2} \mathrm{O}_{3}(0.24-$ 0.84 масс. \%). Кристаллы клинопироксена из основной массы имеют несколько иной состав, они более железистые и марганцовистые, но менее кальциевые и глиноземистые $\left(\mathrm{Wo}_{37.40-28.87} \mathrm{En}_{38.9-40.77} \mathrm{Fs}_{23.7-30.24}\right)$.

Ортопироксен слагает мелкие (до 0.8 мм) удлиненно-призматические однородные 
кристаллы, по составу отвечающие бронзиту $\left(\mathrm{Wo}_{3.43-3.98} \mathrm{En}_{72.22-71.62} \mathrm{Fs}_{24.34-24.40}\right)$.

В основной массе присутствуют лейсты лабрадора и андезина (57-43 мол.\% An), мелкие кристаллы авгита, а также ксеноморфные зерна титаномагнетита и пижонита $\left(\mathrm{Wo}_{7.91-10.27} \mathrm{En}_{57.81-52.70} \mathrm{Fs}_{34.28-37.03}\right)$. Последний минерал встречается только в плагиоклаздвупироксеновых разностях. Структура пород интерсертальная.

Aндезить - более широко распространенная группа пород среди эффузивных и субвулканических образований тальминского комплекса. Это темно-серые, зеленовато-серые, иногда с сургучным оттенком породы, обладающие порфировой или субафировой структурой и массивной текстурой. По соотношению минераловвкрапленников среди них выделяются три петрографические разности: плагиоклазовая, плагиоклаз-амфибол-клинопироксеновая и плагиоклаз-ортопироксен-клинопироксеновая. Две первые разновидности в большей мере характерны для лав, встречающихся в окрестностях с. Рубиновка.

Плагиоклаз является преобладающим минералом-вкрапленником. Он образует шестоватые, реже таблитчатые кристаллы, размеры которых варьируют от долей миллиметра до 4 мм. В плагиоклазовых и плагиоклаз-амфибол-клинопироксеновых андезитах наблюдается обилие крупных (до 3 мм) кристаллов плагиоклаза, иной раз составляющих до $25 \%$ от объема породы. По составу это лабрадоры (69-55 мол. \% An) и андезины (43-42 мол. \% An). Нередко кристаллы плагиоклаза частично пелитизированы. Отдельным зернам минерала присуща зональность нормального типа: центр - 69-57 мол. \% An, край 52-42 мол. \% An. Иногда вкрапленники плагиоклаза окружены каймой, сложенной олигоклазом (13-19 мол.\% Аn). В отдельных образцах плагиоклаз-двупироксеновых андезитов встречаются зерна битовнита (An 84-74) с резко выраженной прямой 30нальностью (81-74 мол. \% An в центральной и 61-60 мол. \% An в краевой части).

Клинопироксен встречается преимущественно в плагиоклаз-двупироксеновых андезитах. Он образует единичные мелкие и крупные (до 1 мм) вкрапленники таблитчатой или шестоватой формы, которые по составу классифицируются как авгит (Wo ${ }_{42.58-41.25}$ En ${ }_{40.31-41.97} \mathrm{Fs}_{17.11-16.78}$ ). Отдельные зерна минерала окружены пижонитовой каймой. В плагиоклаз-амфибол-клинопироксеновых андезитах вкрапленники моноклинного пироксена встречаются весьма редко, при этом они, как правило, полностью карбонатизированы. Тем не менее изредка среди них попадаются зерна, в которых обнаружены реликты авгита $\left(\mathrm{Wo}_{44.96-42.98} \mathrm{En}_{38.05-39.77} \mathrm{Fs}_{16.9-17.25}\right)$, незамещенные целиком вторичными минералами.

Ортопироксен установлен только в плагиоклаз-двупироксеновых андезитах. Количественно он занимает доминирующее положение относительно клинопироксена. Минерал чаще всего представлен мелкими зернами таблитчатой формы, и редко довольно крупными таблитчатыми или шестоватыми кристаллами размером до 0.2 мм. По составу они относятся к бронзиту $\left(\mathrm{Wo}_{2.80-3.16} \mathrm{En}_{68.06-66.24} \mathrm{Fs}_{28.78-27.36}\right)$, реже гиперстену $\left(\mathrm{Wo}_{3.00-2.71} \mathrm{En}_{65.66-66.85} \mathrm{Fs}_{31.31-30.44}\right)$ либо переходным разностям между бронзитом и гиперстеном $\left(\mathrm{Wo}_{3.01-2.80} \mathrm{En}_{67.43-68.06}\right.$ $\left.\mathrm{Fs}_{29.55-29.14}\right)$. Для отдельных зерен ортпироксена характерна зональность прямого типа $\left(\mathrm{En}_{68.30-67.45} \mathrm{Fs}_{28.83-29.14}\right.$ - в центральной части и $\mathrm{En}_{62.79-64.98} \mathrm{Fs}_{34.34-32.36}$ - в краевой части кристалла).

Кристаллы орто- и клинопироксена, а также титаномагнетита иногда образуют небольшие гломеропорфировые скопления.

Амфибол присутствует в отдельных лавовых потоках андезитов в парагенезисе с авгитом. Он образует мелкие (до 0.8 мм) шестоватые кристаллы буро-зеленоватого цвета, которые в значительной степени замещены хлорит-эпидотовым агрегатом.

Основная масса сложена лейстами и микролитами плагиоклаза (58-43 мол. \% An), мелкими зернами титаномагнетита, авгита $\left(\mathrm{Wo}_{37.75-33.45} \mathrm{En}_{38.64-40.53} \mathrm{Fs}_{23.61-26.01}\right)$, а также ксеноморфными кристаллами ортпироксена и пижонита. Последние два минерала встречаются только в плагиоклаз-двупироксеновых андезитах, тогда как кристаллы авгита присутствуют главным образом в плагиоклазовых разновидностях. Структура основной массы интерсертальная либо близкая к микролитовой.

Дацчиты тальминского комплекса характеризуются плагиоклаз-клинопироксеновым парагенезисом минералов-вкрапленников и представляют собой темно-серые, иногда с сургучным оттенком породы, с массивной текстурой и порфировой либо субафировой структурой.

Во вкрапленниках преобладает плагиоклаз, который по составу относится к ряду андезин-лабрадор (55-45 мол.\% $\mathrm{An).} \mathrm{Довольно} \mathrm{часто} \mathrm{кристаллы} \mathrm{минерала}$ 
обнаруживают зональность прямого типа (51-50 мол. \% An в центральной части и 4645 мол.\% An в краевой части). Изредка встречаются зерна битовнита (81-75 мол. \% An), внешние зоны которого сложены лабрадором (51-56 мол. \% An).

Клинопироксен присутствует в породе в виде небольших (до 0.4 мм) таблитчатых, реже удлиненно призматических кристал- лов, соответствующих по составу авгиту $\left(\mathrm{Wo}_{43.94-40.53} \mathrm{En}_{41.93-40.48} \mathrm{Fs}_{14.13-18.99}\right)$. Зональность проявлена слабо. Количество вкрапленников клинопироксена в дацитах обычно не превышает $3 \%$.

Основная масса состоит из микролитов плагиоклаза (47-28 мол. \% An), а также ксеноморфных зерен титаномагнетита, ее структура гиалопилитовая, фельзитовая.
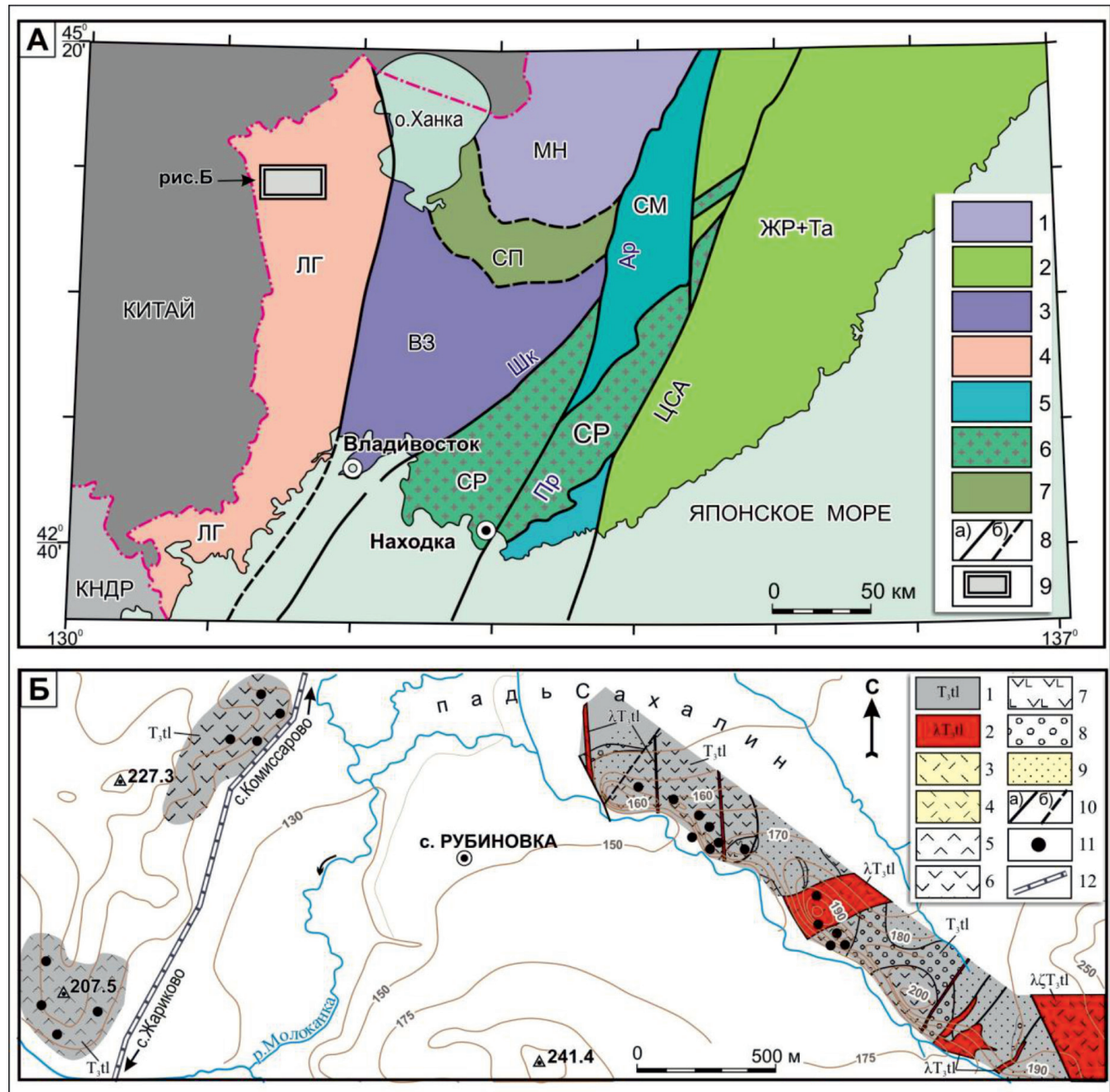

Рис. 1. Схема террейнов Юго-Западного Приморья по [1] (А) и схема опробования тальминской толщи в окрестностях с. Рубиновка (Б). Для рис. 1, А: 1-3-террейны раннепалеозойского БуреяЦзямусы-Ханкайского орогенного пояса: 1 - Матвеевско-Нахимовский (МН), метаморфический,

2 - Спасский (СП), фрагмент раннекембрийской аккреционной призмыл, 3 - Вознесенский (В3),

фрагмент раннекембрийской пассивной окраины; 4 - Лаоелин-Гродековский террейн (ЛГ) позднепалеозойского-раннемезозойского Солонкерского орогенного пояса - фрагмент активной окраины; 5-7-террейны мезозойского Сихотэ-Алинь-Северо-Сахалинского орогенного пояса:

5 -Самаркинский террейн (CM), фрагмент юрской аккреционной призмы, 6-Сергеевский террейн (СР), 7 - Журавлевский и Таухинский терейны - фрагменты раннемеловой окраины Азии; 8 - разломы: Пр - Партизанский, Шк-Шкотовский, Ар - Арсеньевский, ЦСА - Центральный Сихотэ-Алиньский; 9 - положение района исследований. Для рис. 1, Б: 1 - тальлинская толщатуфопесчаники, конгломераты, лавы андезитов, туфоалевролиты; 2 - тальминский комплекс-

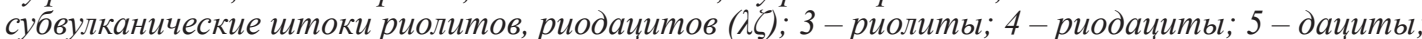
6-андезиты; 7 - андезибазальты; 8 -конгломераты; 9 - туфопесчаники; 10 - разломы установленные (а) и предполагаемые (б); 11 - точки отбора проб; 12 - грунтовая дорога 


\section{Геохимическая характеристика}

Содержание кремнезема в проанализированных образцах тальминского комплекса изменяется в интервале от 52 до 63 масс. \%, в соответствии с чем точки составов пород располагаются на диаграмме $\mathrm{SiO}_{2}-$ $\left(\mathrm{Na}_{2} \mathrm{O}+\mathrm{K}_{2} \mathrm{O}\right)$ в полях андезибазальтов, андезитов и дацитов. Судя по содержанию суммы щелочей, весь ряд вулканических пород имеет нормальный тип щелочности (рис. 2, А). По соотношению кремнезема и $\mathrm{K}_{2} \mathrm{O}$ (рис. 2 , Б) все они соответствуют умереннокалиевым разностям известковощелочной серии, располагаясь на диаграмме AFM (диаграмма не приводится) в поле известково-щелочных магм. По другим петрохимическим параметрам андезибазальты комплекса обладают натриевой специализацией $\quad\left(\mathrm{Na}_{2} \mathrm{O} / \mathrm{K}_{2} \mathrm{O}=3.84-5.69\right)$, а по содержанию глинозема принадлежат к высокоглиноземистым разностям $(\mathrm{al}=1.58-2.37)$. Из других особенностей андезибазальтов следует отметить низкую магнезиальность $(\mathrm{Mg} \#=0.26-0.29)$ и высокое содержание $\mathrm{CaO}$. Средние и кислые породы комплекса - андезиты и дациты - относятся к высокоглиноземистым и весьма высокоглиноземистым разностям $(\mathrm{al}=1.35-2.54)$ калиево-натриевого ряда $\left(\mathrm{Na}_{2} \mathrm{O} / \mathrm{K}_{2} \mathrm{O}=2.70-3.25\right)$, их магнезиальность составляет от 0.17 до 0.35 . Следует отметить, что для андезитов комплекса характерен относительно широкий диапазон значений магнезиальности - от 0.19 до 0.35 .
По этому параметру андезиты можно разделить на две группы: низкомагнезиальные $(\mathrm{Mg} \#=0.19-0.30)$ и умеренномагнезиальные $(\mathrm{Mg} \#=0.32-0.35)$.

В целом изученные вулканиты тальминского комплекса формируют единые тренды вариаций составов, демонстрирующие с ростом $\mathrm{SiO}_{2}$ (от базальтов до дацитов) снижение содержаний $\mathrm{MgO}, \mathrm{TiO}_{2}$, $\mathrm{CaO}$ и увеличение $-\mathrm{P}_{2} \mathrm{O}_{5}, \mathrm{~K}_{2} \mathrm{O}, \mathrm{Na}_{2} \mathrm{O}$. Концентрации $\mathrm{FeO}$ и $\mathrm{Al}_{2} \mathrm{O}_{3}$ отрицательно коррелируют с кремнекислотностью пород, хотя такая зависимость проявлена недостаточно отчетливо. Исключением среди пород комплекса являются умеренномагнезиальные $(\mathrm{Mg} \#=0.32-0.35)$ андезиты, выделяющиеся заметно более высокими содержаниями $\mathrm{MgO}$ по сравнению со всеми остальными вулканитами и, как следствие, не располагающиеся на общем тренде.

Геохимической особенностью изученных вулканитов тальминского комплекса являются высокие концентрации в них таких некогерентных элементов, как $\mathrm{Rb}, \mathrm{Ba}$, $\mathrm{Sr}, \mathrm{Zr}, \mathrm{U}$, и низкие - Th, Nb, Ta (рис. 3, A). По мере возрастания кремнекислотности пород отмечается отчетливая тенденция к увеличению содержания большей части некогерентных элементов ( $\mathrm{Rb}, \mathrm{Ba}, \mathrm{U}, \mathrm{Th}$, $\mathrm{Nb}, \mathrm{Hf})$, тогда как концентрации $\mathrm{Sc}$ заметно уменьшаются. В поведении $\mathrm{Sr}$ наблюдается несколько иной характер распределения, а именно: содержание этого элемента сначала возрастает от андезибазальтов к андезитам, а затем в дацитах вновь падает.
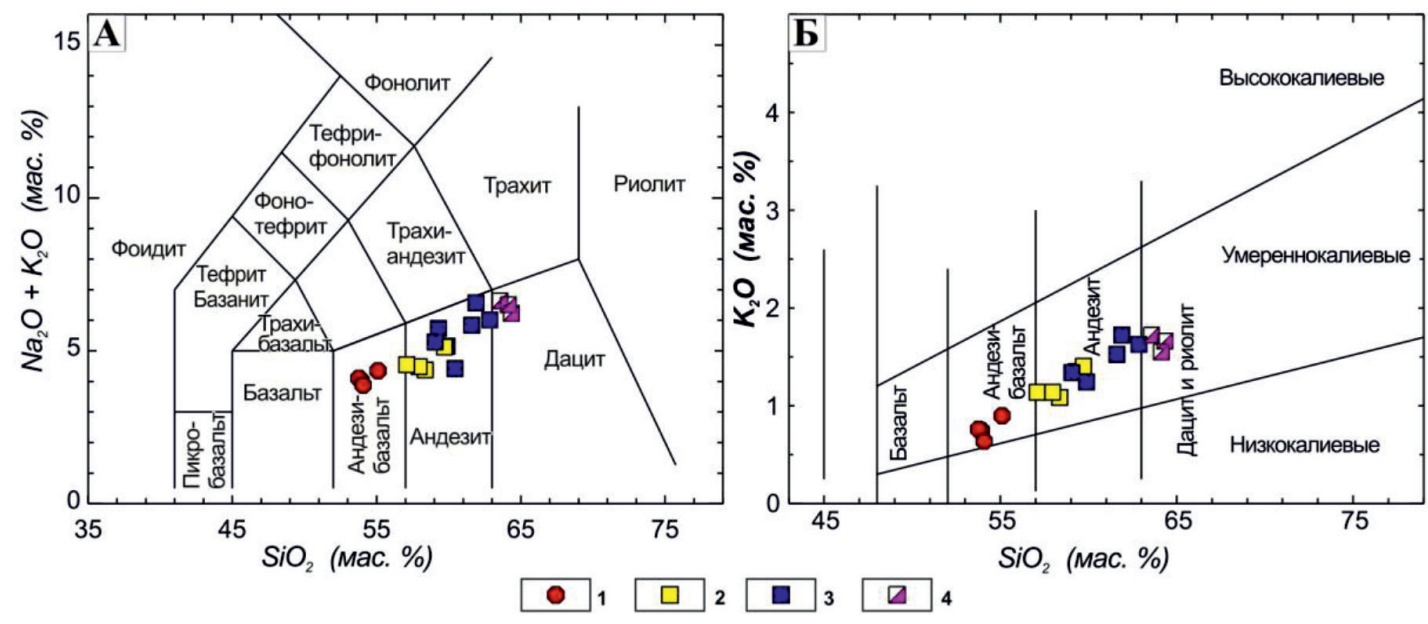

Pис. 2. Классификационные диаграммы $\mathrm{SiO}_{2}-\mathrm{Na}_{2} \mathrm{O}+\mathrm{K}_{2} \mathrm{O}$ (A) и $\mathrm{SiO}_{2}-\mathrm{K}_{2} \mathrm{O}$ (A) $\mathrm{SiO}_{2}-\mathrm{Na}_{2} \mathrm{O}+\mathrm{K}_{2} \mathrm{O}$ (Б) для пород тальминского комплекса: 1 - андезибазальт, 2 - умеренномагнезиальньий андезит, 3 - низкомагнезиальный андезит, 4 - дацит. Составы приведены к 100\% с вычетом потерь при прокаливании 

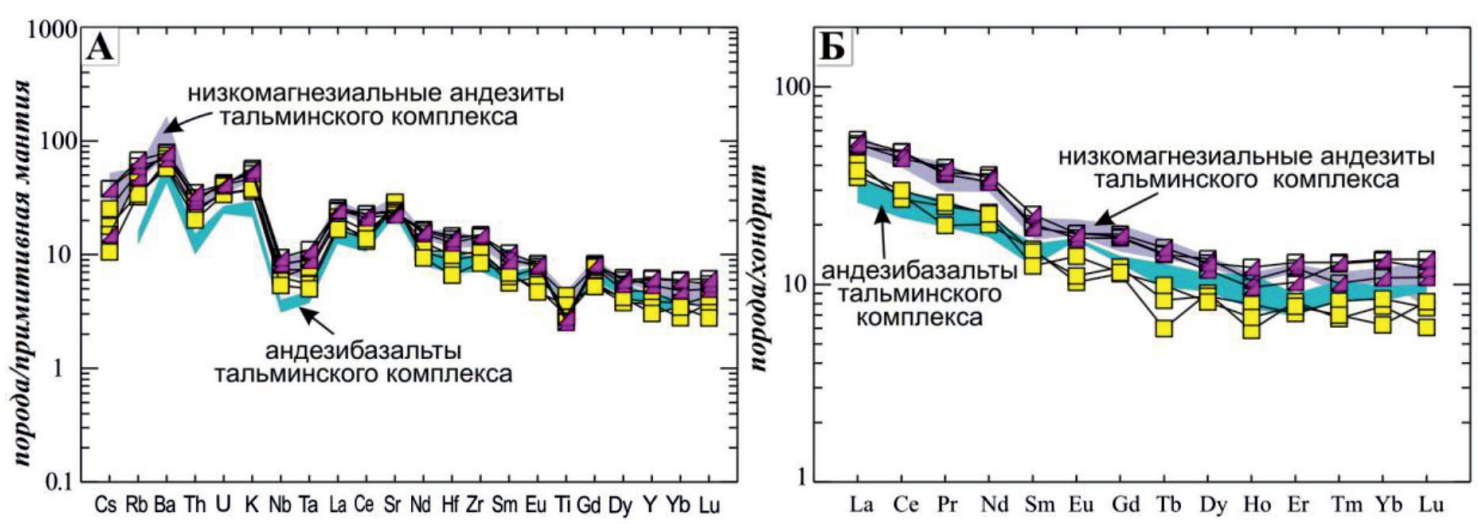

Рис. 3. Спектры распределения редкоземельных и редких элементов, нормализованных к примитивной мантии (А) и к хондриту (Б) в породах тальминского комплекса. Условные обозначения смотри на рис. 2

Анализ распределения редкоземельных элементов (REE) в изученных вулканитах показал, что для андезибазальтов свойственны умеренные содержания REE $(\Sigma \mathrm{REE}+\mathrm{Y}=69.72-95.63$ г/т) с преобладанием легких лантаноидов над тяжелыми $\left((\mathrm{La} / \mathrm{Yb})_{\mathrm{n}}=3.23-4.85\right)$, а также наличие положительной $\mathrm{Eu}-$ аномалии $\left(\mathrm{Eu} / \mathrm{Eu}^{*}=1.18\right.$ 1.30). Отметим, что для андезибазальтов свойственны также повышенные концентрации $\mathrm{CaO}$ и $\mathrm{Al}_{2} \mathrm{O}_{3}$. Возможно, данные характеристики вулканитов связаны с присутствием в них высококальциевого кумулятивного плагиоклаза.

В болеекислых разностях комплекса-андезитах и дацитах, отмечено увеличение содержания практически всех редкоземельных элементов $(\Sigma \mathrm{REE}+\mathrm{Y}=105.60-126.72 \Gamma / \mathrm{T}$ и 128.6-134.1 г/т соответственно). Отношение $(\mathrm{La} / \mathrm{Yb})_{\text {n }}$ изменяется в узком интервале значений (3.92-5.37 и 3.97-4.81 соответственно) и сопоставимо с таковым в андезибазальтах. Типичным для данных пород является отсутствие Еu-аномалии (Eu/ $\left.\mathrm{Eu}^{*}=0.82-1.06\right)$ в спектрах распределения REE (рис. 4, Б).

Между тем наиболее магнезиальные разности андезитов по сравнению с остальными умеренно кислыми лавами комплекса обладают более низкими суммарными концентрациями $\mathrm{REE}$ ( $\Sigma \mathrm{REE}+\mathrm{Y}=77.76$ 84.61 г/т), сопоставимыми с таковыми в андезибазальтах. Им также присуща более высокая степень фракционирования REE ((La/Yb)n=4.66-6.25). В отдельных образцах данных андезитов отмечено наличие слабой отрицательной Еu-аномалии $\left(\mathrm{Eu} / \mathrm{Eu}^{*}=0.7-0.82\right)$, что свидетельствует об ограниченной роли плагиоклаза в процессах фракционирования.

\section{Результаты исследования и их обсуждение}

\section{Условия кристаллизацчии вулканитов тальминского комплекса}

Для реконструкции физико-химических условий кристаллизации умеренно кислых и кислых магматических пород тальминского комплекса были использованы современные геотермобарометры [8; 9], основанные на экспериментальных данных равновесия «минерал - расплав». Помимо этого, расчет условий формирования пород проводился с использованием компьютерной программы QUILF [10].

Основой для оценки Р-Т условий кристаллизации темноцветных минералов из вулканических пород комплекса с применением минеральных геотермобарометров [8; 9], послужили валовые составы пород и микрозондовые анализы Срх или Орх, в зависимости от типа термобарометра. Граничными условиями расчетов параметров кристаллизации в системе «минерал - расплав» были для клинопироксенов $\mathrm{K}_{\mathrm{D}} \mathrm{Fe} / \mathrm{Mg}=0.27 \pm 0.03$, а для ортопироксенов $\mathrm{K}_{\mathrm{D}} \mathrm{Fe} / \mathrm{Mg}=0.29 \pm 0.06$ при принятых для расплавов следующих параметрах $\mathrm{FeO} / \mathrm{FeO}_{\text {общ }}=1, \quad \mathrm{H}_{2} \mathrm{O}=$ П.П.П. $\quad$ (масс. \%). Величины ошибок используемых геобарометров и геотермометров составляют $\mathrm{T} \pm 30^{\circ} \mathrm{C}$ и $\mathrm{P} \pm 1.5$ кбар [8; 9]. Следует отметить, что при расчетах использовались составы только центральных частей вкрапленников и субфенокристаллов мине- 
ралов, краевые части не рассчитывались ввиду сложности, а иногда невозможности достижения должного равновесного отношения $\mathrm{K}_{\mathrm{D}}$.

Результаты расчетов РТ-условий кристаллизации Срх и Орх из андезибазальтов в системе «пироксен - расплав» показали, что формирование вкрапленников клинопироксена происходило в интервале Т $=1076$ $1061^{\circ} \mathrm{C}, \mathrm{P}=4.99-4.76$ кбар, ортопироксена $-\mathrm{T}=1077-1072^{\circ} \mathrm{C}, \mathrm{P}=2.57-2.0$ кбар. Близкий интервал значений температур кристаллизации $\left(\mathrm{T}=1073-1040^{\circ} \mathrm{C}\right)$ был получен для этих же образцов при оценке двупироксенового равновесия с применением программы QUILF [10].

$\mathrm{B}$ соответствии с полученными по минеральным геотермобарометрам [8; 9] данными, кристаллизация клино- и ортопироксенов из умеренномагнезиальных андезитов комплекса происходила в близких диапазонах температур и давлений: клинопироксен $-\mathrm{T}=1099-1088^{\circ} \mathrm{C}, \mathrm{P}=3.78-2.87$ кбар; ортопироксен - $\mathrm{T}=1095-1076{ }^{\circ} \mathrm{C}, \mathrm{P}=3.83$ 2.45 кбар. Температура двупироксенового равновесия, рассчитанная с помощью программы QUILF по этим же кристаллам клино- и ортопироксенов, составляет 1041$1017^{\circ} \mathrm{C}$. Кристаллизация клинопироксенов из низкомагнезиальных андезитов согласно геотермобарометру [9] происходила при более низких температурах - 1014-996 ${ }^{\circ} \mathrm{C}$, в условиях давлений равновесия «клинопироксен - расплав» $\mathrm{P}=3.71-3.04$ кбар. Наиболее низкие значения давления и температуры кристаллизации установлены для вкрапленников клинопироксена из дацитов $-\mathrm{T}=993-983^{\circ} \mathrm{C}, \mathrm{P}=2.43-2.31$ кбар.

\section{Геодинамическая типизация умеренно} кислых вулканитов комплекса

Как отмечалось выше, для изученных вулканитов комплекса свойственны высокие содержания крупноионных литофильных элементов ( $\mathrm{Sr}, \mathrm{Rb}, \mathrm{Ba})$ при устойчивом дефиците в отношении некоторых высокозарядных элементов (Nb, Ta, Ti). В этой связи на многокомпонентных диаграммах, нормализованных к примитивной мантии, в спектрах всех вулканитов комплекса вне зависимости от их состава присутствуют хорошо выраженные положительные аномалии для $\mathrm{Ba}, \mathrm{K}, \mathrm{Sr}$, а также отрицательные для $\mathrm{Nb}$, Та и Тi (рис. 3, А). Подобные геохимические особенности считаются типичными для вулканических пород зон субдукции. На это же также указывает расположение точек их составов на дискриминантных диаграммах Th-Hf/3-Та и Th-Hf/3-Nb/16 в полях вулканитов островных дуг и активных континентальных окраин (рис. 4, А, Б).

На диаграмме $\mathrm{Nb} / \mathrm{La}$ - $\mathrm{Ba} / \mathrm{La}$ все проанализированные вулканиты тальминского комплекса также попадают в поле надсубдукционных пород (орогенные андезиты), обладающих низкими $\mathrm{Nb} / \mathrm{La}$ и повышенными $\mathrm{Ba} / \mathrm{La}$ отношениями (рис. 5 , A). Это же демонстрирует диаграмма $\mathrm{Th} / \mathrm{Yb}-\mathrm{Ta} / \mathrm{Yb}$, на которой изученные андезибазальты, имея умеренные величины $\mathrm{Th} / \mathrm{Yb}(0.50-0.81)$ и $\mathrm{Ta} / \mathrm{Yb}$ (0.07-0.12) отношений, располагаются в поле вулканитов островных дуг (рис. 5, Б).
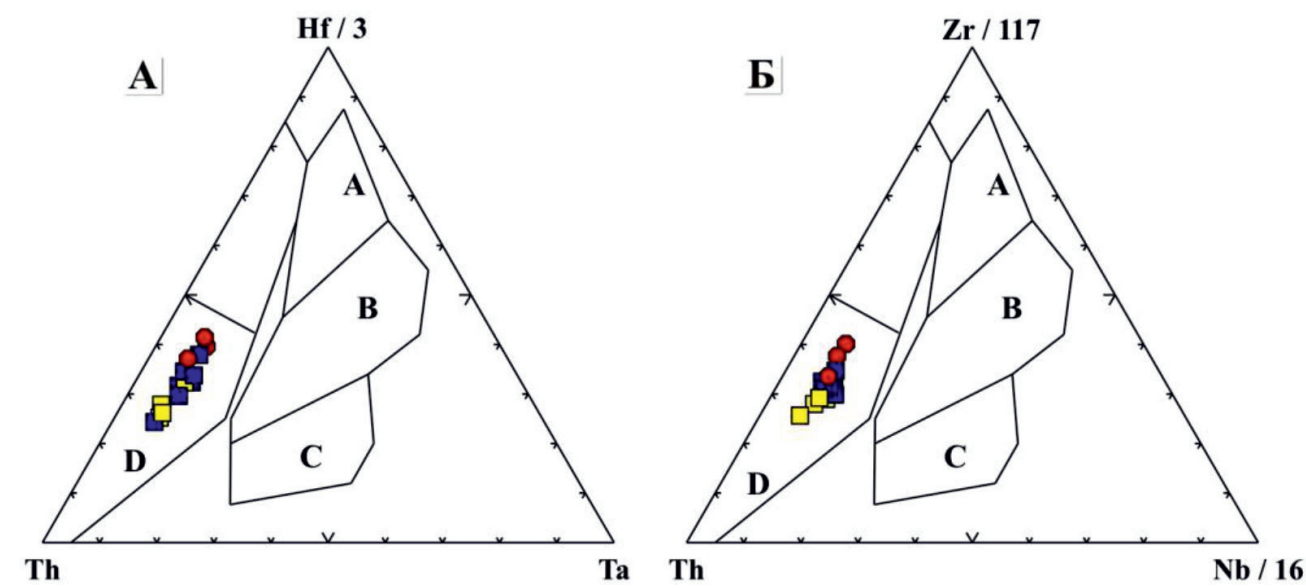

Рис. 4. Составы андезибазальтов и андезитов тальминского комплекса на дискриминантных диаграммах Th-Hf/3-Ta (A) и Th-Hf/3-Nb/16 (Б). Полями на диаграмме обозначень:

A-геодинамические обстановки срединно-океанических хребтов, B-срединно-океанических

хребтов и внутриплитные обстановки, $C$ - внутриплитные обстановки, $D$ - островных дуг и активных континентальных окраин. Условные обозначения смотри на рис. 2 

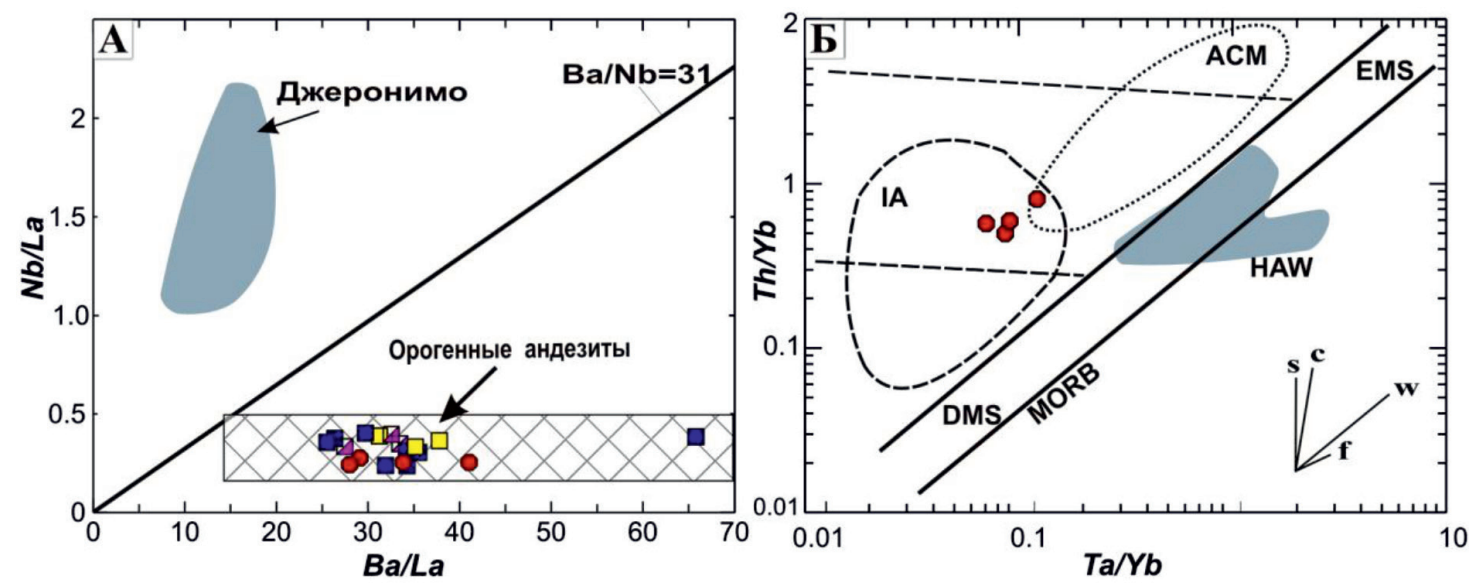

Рис. 5. Положение составов вулканитов тальминского комплекса на дискриминантных диаграммах Ba/La-Nb/La (A) и Ta/Yb-ThYb (Б). На диаграмме Ba/La-Nb/La показаны поля: базальтов Джеронимо, имеющих типичные характеристики астеносферного материала активной континентальной окраины Запада США и орогенных андезитов.

Полями на диаграмме Ta/Yb-ThYb показаны составы базальтов: островных дуг (IA), активных континентальных окраин (ACM) и гавайских островов (НAW);

$D M S$ - деплетированная мантия; EMS - обогащенная мантия.

Векторы изменения состава пород за счет: $S$ - субдукиионных компонентов,

$C$ - контаминации континентальной коры, $W$ - внутриплитного (мантийного) обогащчения литофильными элементами, F- фракционной кристаллизацฺии.

Условные обозначения смотри на рис. 2

Однако имеющиеся на сегодняшний день геологические данные о строении Лаоелин-Гродековского террейна свидетельствуют о том, что формирование вулканитов тальминского комплекса едва ли осуществлялось непосредственно в надсубдукционной обстановке. На это, прежде всего, указывает отсутствие в составе террейна фрагментов аккреционного клина, а также базальтов океанической коры триасового возраста. Обращает на себя внимания и то, что триасовые вулканиты не формируют в пределах Лаоелин-Гродековского террейна единый протяженный линейный вулканический пояс, являющийся одним из структурных элементов, присущий островным дугам.

На основании вышеизложенного можно предположить, что надсубдукционные геохимические признаки пород комплекса связаны с участием в петрогенезисе блоков континентальной литосферы, метасоматически переработанных предшествующими тектономагматическими процессами, в результате которых она приобрела надсубдукционные микроэлементные характеристики. Аналогичная точка зрения ранее была высказана в работах, посвященных изучению позднекайнозойских базальтов юга Дальнего Востока России $[11 ; 12]$ и се- веро-востока Китая [13]. Таким событием в рассматриваемом регионе, по-видимому, следует считать позднепермскую субдукцию. Об этом может свидетельствовать то, что для пермских базальтов, расположенных на юге Лаоелин-Гродековского террейна в районе мыса Мраморный, установлены ярко выраженные «надсубдукционные» геохимические характеристики [14]. Следует отметить, что следы пермской субдукции отмечаются также на сопредельных территориях Кореи и Китая в виде комплексов аккреционных призм, содержащих фрагменты позднепалеозойских офиолитовых разрезов [15].

Таким образом, полученные данные позволяют предполагать участие в магмогенезисе изученных пород тальминского комплекса континентальной литосферной мантии, метасоматически преобразованной в ходе предшествующей позднепермской субдукции.

\section{Выводы}

Принимая во внимание несоответствие геологических данных о строении Лаоелин-Гродековского террейна (а именно отсутствие фрагментов аккреционного клина, а также пород океанической коры триасового возраста) и наличии у вулканитов позд- 
нетриасового возраста надсубдукционных геохимических характеристик (повышенные содержания $\mathrm{Sr}, \mathrm{Rb}, \mathrm{Ba}$ и низкие - Nb, Ti и Та), можно сделать заключение об участии в происхождении этих пород мантийного вещества, метасоматически переработанного в ходе предшествующей позднепермской субдукции.

Полученные результаты оценки РТпараметров кристаллизации изученных пород тальминского комплекса свидетельствуют об относительно высокотемпературной природе как андезибазальтов, так и умеренномагнезиальных андезитов комплекса. При этом кристаллизация андезибазальтов происходила в интервале давлений 2-5 кбар, что отвечает глубине 6-15 км, тогда как формирование умеренномагнезиальных андезитов протекало при несколько более низких значениях давлений 2-4 кбар на глубине не более 12 км.

Кристаллизация же низкомагнезиальных андезитов и дацитов, как и следовало ожидать, проходила при более низких температурах, при этом давление в расплаве не превышало 2-4 кбар, что отвечает глубине 6-12 км.

Исследования выполнены при финансовой поддержке РФФИ, гранта № 19-05-00229A.

\section{Список литературы / References}

1. Голозубов В.В. Террейны Северо-Восточного Китая и прилегающих районов Российского Дальнего Востока / Фундаментальные проблемы тектоники и геодинамики: материалы LII Тектонического совещания (г. Москва, 28 января - 1 февраля 2020 г.). М.: ГЕОС, 2020. Т. 1. С. 182-185.

Golozubov V.V. Terranes of Northeastern China and adjacent territories of Russian Far East // Fundamental'nyye problemy tektoniki i geodinamiki: materialy LII Tektonicheskogo soveshchaniya (g. Moskva, 28 yanvarya -1 fevralya 2020 g.) M.: GEOS, 2020. Vol. 1. P. 182-185 (in Russian).

2. Триас и юра Сихотэ-Алиня / Под ред. П.В. Маркевича, Ю.Д. Захарова. Владивосток: Дальнаука, 2004. Кн. 1. 417 с.

Triassic and Jurassic of the Sikhote-Alin / Edited by P.V. Markevicha, Yu.D. Zakharova Vladivostok: Dal'nauka, 2004. Vol. 1. 417 p. (in Russian).

3. Государственная геологическая карта Российской Федерации. Масштаб 1:200 000. Серия Ханкайская. Листы K-52-XI, XVII. Объяснительная записка / Под ред. Н.К. Цесарский. М.: МФ ВСЕГЕИ, 2013. 144 с.

State geologic map of Russian Federation. Scale 1:200 000 Seriya Khankaiskaya. Listy K-52-XI, XVII. Ob'yasnitelnaya zapiska / Pod red. N.K. Caesarsky M.: MF VSEGEI, 2013. 144 p. (in Russian).

4. Государственная геологическая карта Российской Федерации 1:1 000000 (третье поколение). Дальневосточная серия. Лист L-52 (Пограничный), L-53 (Ханка), К-52 (Владивосток) К-53 (Находка). Объяснительная записка / Под ред. С.В. Коваленко. СПб.: Картограф. фабрика ВСЕГЕИ, 2011. $684 \mathrm{c}$.

State Geologic Map of the Russian Federation 1:1 000000 (Third Edition). Far East Series. Sheets L-52 (Pogranichniy), L-53 (Khanka), K-52 (Vladivostok), K-53 (Nakhodka). Ob'yasnitelnaya zapiska / Pod redaktsiey S.V. Kovalenko. Spb: Kartograf. Fabrika VSEGEI, 2011. 684 p. (in Russian).

5. Чащин С.А., Попов В.К., Чащин А.А., Будницкий С.Ю. Новые результаты минералого-геохимических и изотопно-геохронологических исследований триасового вулканизма южного Приморья (на примере изучения Тальминской вулканоструктуры) // IX Сибирская конференция молодых ученых по наукам о Земле: материалы конференции (Новосибирск, 19-23 ноября 2018 г.). Новосибирск, 2018. C. 673-676.

Chashchin S.A., Popov V.K., Chashchin A.A., Budnitskiy S.Yu. New data on mineralogical and geochemical, isotopic and geochronological research of Triassic volcanism in the southern Primorye (on the example of Talminskaya volcanic edifice) // IX Sibirskaya konferentsiya molodykh uchenykh po naukam o Zemle: materialy konferentsii (Novosibirsk, 19-23 noyabrya 2018 g.). Novosibirsk, 2018. P. 673-676 (in Russian).

6. Xu W.L., Pei F.P., Wang F., Meng E., Ji W.Q., Yang D.B., Wang W. Spatial-temporal relationships of Mesozoic volcanic rocks in NE China: Constraints on tectonic overprinting and transformations between multiple tectonic regimes. Journal of Asian Earth Sciences. 2013. V. 74. P. 167-193. DOI: 10.1016/j. jseaes.2013.04.003.

7. Маркевич П.В., Шорохов В.И. Геологическая карта СССР. Масштаб 1:200 000 (серия Сихотэ-Алинская). Лист L-52-XXX. Объяснительная записка. Л.: Б.и., 1974. 48 с.

Markevich P.V., Shorokhov V.I. Geologic map of the USSR. Scale 1:200 000 (Sikhote-Alin series). Sheet L-52-XXX. Obyasnitelnaya zapiska. L.: B.i., 1974. 48 p. (in Russian).

8. Neave D.A., Putirka K.D. A new clinopyroxene-liquid barometer, and implications for magma storage pressures under Icelandic rift zones. American Mineralogist. 2017. V. 102. P. 777-794. DOI: 10.2138/am-2017-5968.

9. Yavuz F., Yildirim D. A Windows program for pyroxeneliquid thermobarometry. Periodico di Mineralogia. 2018. V. 87. No. 2. P. 149-172. DOI: 10.2451/2018PM787.

10. Frost B.R., Lindsley D.H. Equilibria among Fe-Ti oxides, pyroxenes, olivine and quartz: Part 2: Application. Amer. Mineral. 1992. Vol. 77. P. 1004-1020.

11. Чашин А.А., Мартынов Ю.А., Рассказов С.В., Максимов С.О., Брандт И.С., Саранина Е.В. Изотопно-геохимическая характеристика позднемиоценовых субщелочных и щелочных базальтов юга Дальнего Востока России как показатель роли континентальной литосферы в их происхождении // Петрология. 2007. Т. 15. № 6. С. 656-681.

Chashchin A.A., Martynov Yu.A., Rasskazov S.V., Maksimov S.O., Brandt I.S., Saranina E.V. The isotopic geochemistry of late Miocene subalkaline and alkaline basalts in the south of Russian Far East as an indicator for the role of continental lithosphere in their origin // Petrology. 2007. V. 15. P. 575-598. DOI: 10.1134/S0869591107060045.

12. Мартынов Ю.А., Ханчук А.И. Кайнозойский вулканизм Восточного Сихотэ-Алиня: результаты и перспективы петрологических исследований // Петрология. 2013. Т. 21. № 1. C. 94-108. DOI: 10.7868/S0869590313010068.

Martynov Y.A., Khanchuk A.I. Cenozoic volcanism of the eastern Sikhote Alin: petrological studies and outlooks // Petrology. 2013. V. 21. No. 1. P. 85-99. DOI: 10.1134/ S0869591113010049.

13. Kuritani T., Ohtani E., Kimura J.-I. Intensive hydration of the mantle transition zone beneath China caused by ancient slab stagnation. Nature Geoscience. 2011. V. 4. P. 713-716. DOI: $10.1038 /$ ngeo 1250 .

14. Голозубов В.В., Крук Н.Н., Киселев В.И., Руднев С.Н., Касаткин С.А., Крук Е.А. Первые свидетельства среднетриасового вулканизма в южном Приморье // Тихоокеанская геология 2017. T. 11. № 2. C. 110-122. DOI: 10.1134/ S1819714017020038.

Golozubov V.V., Kruk N.N., Kiselyov V.I., Kasatkin S.A., Rudnev S.N., Kruk E.A. Firtst evidence for the Middle Triassic volcanism in South Primorye // Tikhookeanskaya geologiya. 2017. V. 11. No. 2. P. 110-122 (in Russian).

15. Парфенов Л.М., Берзин Н.А., Ханчук А.И., Бадарч Г., Беличенко В.Г., Булгатов А.Н., Дриль С.И., Кириллова Г.Л., Кузьмин М.И., Ноклеберг У., Прокопьев А.В., Тимофеев В.Ф., Томуртогоо О., Янь Х. Модель формирования орогенных поясов Центральной и Северо-Восточной Азии // Тихоокеанская геология. 2003. Т. 22. № 6. С. 1-41.

Parfenov L.M., Berzin N.A., Khanchuk A.I., Badarch G., Belichenko V.G., Bulgatov A.N., Dril S.I., Kirillova G.L., Kuzmin M.I., Nokleberg W.J., Prokopyev A.V., Timofeev V.F., Tomurtogoo O., Yang H. A model for the formation of orogenic belts in central and Northeast Asia // Tikhookeanskaya geologiya. 2003. V. 22. No. 6. P. 1-41 (in Russian). 